\title{
Changes in the acquisition and consumption of food plants and their relationship with indigenous perceptions of health in a Guarani village, São Paulo, Brazil
}

\author{
Nayara Scalco ${ }^{1,2}$ and Eliana Rodrigues ${ }^{2, *}$ \\ 'Department of Psychobiology, Universidade Federal de São Paulo, São Paulo, Brazil: ${ }^{2}$ Department of Biological \\ Sciences, Center for Ethnobotanical and Ethnopharmacological Studies (CEE), Universidade Federal de \\ São Paulo, Rua Prof. Artur Riedel 275, Jardim Eldorado Diadema, São Paulo, CEP 09972-270, SP, Brazil
}

Submitted 5 January 2012: Final revision received 10 June 2012: Accepted 17 August 2012: First published online 20 ctober 2012

\begin{abstract}
Objective: The present study investigated Guarani village interviewees' diet changes over time, their perceptions about the changes and the effects of these changes on their health.

Design: The study employed qualitative methods with a sample of Guarani Indians selected by snowball sampling. Ethnographic methods and techniques included field diaries, informal and unstructured interviews and participant observation.

Setting: The Tenondé Porã Guarani village is located in the district of Parelheiros, São Paulo, Brazil. Interviews were conducted from July 2008 to December 2009. Subjects: Fifteen Guarani Indians, males and females in age categories ranging from youths to elders, took part in the study.

Results: The interviewees reported changes in how food was obtained, the occurrence of food substitutions and food species abandonment, recipe changes and the introduction of new foods. Some ritual use of plants was maintained. Disease frequency was found to increase because of this change and a lack of obedience to Nhanderu (the Guarani God). A lack of space for daily traditional activities (e.g. farming, hunting) was found to result in sedentary lifestyles. Conclusions: The village location was a key factor in the Guarani diet change, although some rituals related to available plants were preserved.
\end{abstract}

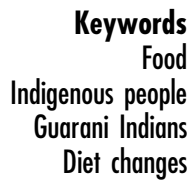

Food acquisition and preparation have changed throughout history $^{(1,2)}$. These changes can be observed in the evolution of food preparation processes. Food was initially eaten raw, but with the discovery of fire, man began cooking his food. This form of preparation was being used for many Indian recipes when the Portuguese arrived in Brazil ${ }^{(3)}$.

The Brazilian indigenous population witnessed the extermination of several of its groups after the encounter of the Old and New Worlds. The focus on protecting, preserving and taking care of the indigenous inhabitants only gained strength in the early 20 th century $^{(4)}$.

Some indigenous populations remain isolated, but others have developed a close relationship with the nonindigenous population and have experienced cultural changes as a result. The cohabitating ethnic groups within 'Brazilian culture' have changed their lifestyles by incorporating non-indigenous elements, such as language, iron tools, firearms and even food. These groups often live in absolute poverty and are increasingly exposed to disease ${ }^{(5)}$.
Throughout the world, changes in diet and lifestyle have been observed in native groups, including the Dogrib Indians $^{(6)}$, Aboriginal peoples ${ }^{(7)}$ in Canada, the Lakota tribe $^{(8)}$, the Alaskan natives ${ }^{(9)}$, the Hmong ${ }^{(10)}$ and others who live in the USA ${ }^{(11,12)}$, the Tepehuanos ${ }^{(13)}$ and Tarahumara $^{(14)}$ in Mexico and the Hindus in India ${ }^{(15)}$. These studies associate some chronic diseases with the above-mentioned changes, such as overweight, obesity, CVD and diabetes, and a sedentary lifestyle.

Several studies have analysed the nutritional status of adults $^{(16)}$, children ${ }^{(17-19)}$ and mother-child dyads ${ }^{(19,20)}$ of Brazilian indigenous groups. Malnutrition was observed at all ages and obesity was found among adults of ethnic groups whose activities were conducted outside the village because traditional village activities, such as farming, fishing, hunting and gathering, are more physically demanding than the activities conducted outside the village. The National Survey of Health and Nutrition of Indigenous Peoples (Inquérito Nacional de Saúde e Nutrição dos Povos Indígenas (INSNPI)) investigated 


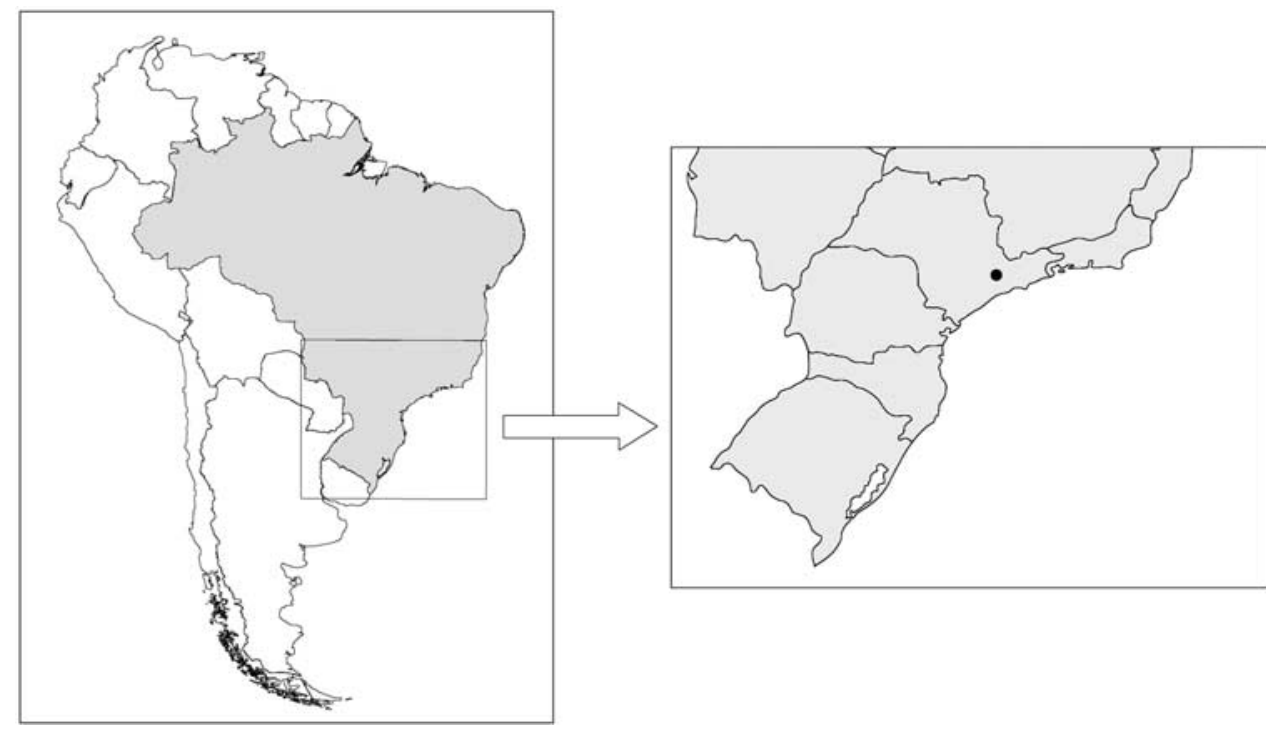

Fig. 1 (Left) Location of Brazil (grey area) in South America; (right) Brazilian states with Guarani villages and the location of the studied village, Tenondé Porã, in the state of São Paulo $(\bullet)$

health, sanitation and social issues in indigenous villages across the country ${ }^{(20,21)}$.

\section{The Guarani nation and study area}

The Tenondé Porã village has a population of approximately 800 people who are part of the Guarani ethnic group, which is currently distributed across approximately eighty villages in several Brazilian states ${ }^{(22)}$ in addition to Argentina, Paraguay and Uruguay (Fig. 1). From an Indian perspective, there are no geographical boundaries; individuals move among these villages and countries and share their habits, food and culture. They speak Guarani as well as Portuguese ${ }^{(23)}$. The studied village is located in an Atlantic forest remnant near the city of São Paulo, one of the most diverse and humanthreatened biomes in Brazil ${ }^{(24)}$. Estimations suggest that 8000 of the biome's 20000 plant species are endemic.

The Tenondé Porã village has had electricity and water since the mid-1990s, but the sewer system remains inadequate. The village has two public schools and one health-care centre. When necessary, patients are referred to hospitals that are $30-45 \mathrm{~km}$ from the village. For many health problems, Karai (shaman) conduct healing rituals in opy (prayer houses). The primary sources of income are social security for the elderly, the sale of handicraft products and social programmes sponsored by the federal government. Indigenous food is grown in small fields and orchards, and non-indigenous food is acquired at food markets that are $1 \cdot 5-10 \mathrm{~km}$ from the village.

The present study investigated Tenondé Porã Guarani interviewees' diet changes over time, their perceptions of the changes and the effects of these changes on their health.

\section{Methods}

\section{Permissions}

Permissions were obtained in accordance with Brazilian law from the following organizations: the National Indian Foundation (Fundação Nacional do Índio (FUNAI), no. 1000/07), the National Council for Scientific and Technological Development (CNPq), the National Council on Ethics in Research (Conselho Nacional de Ética em Pesquisa (CONEP), no. 424/2008) and the Council on Ethics in Research at the Federal University of São Paulo (no. 2023/07). Additionally, prior informed consent was obtained from the village leaders, respecting the requirements of the Genetic Heritage Management Council (Conselho de Gestão do Patrimônio Genético (CGEM)) at the Ministry of Environment (Ministério do Meio Ambiente (MMA), process no. 02000.000919/2007-11).

\section{Fieldwork}

Fieldwork was conducted by one of the authors (N.S.) and consisted of weekly visits from August 2008 to December 2009, which totalled approximately $100 \mathrm{~d}$. The following ethnographic methods and techniques were used ${ }^{(25-28)}$ : field diary reports, informal and unstructured interviews, and participant observation. Traditional food preparation was observed in a Guarani culinary workshop that brought together the village elders, and current food preparation methods were observed in village homes. The checklist technique was used to verify the information that was obtained in interviews and observed at different times.

\section{Village and interviewee selection}

The Tenondé Porã village was selected on advice from anthropologists and health-care technicians working at 
Table 1 Abandonment, acquisition in the maintenance (original, mixed and trade) and substitution of the main plants mentioned by Indians in the Tenondé Porã Guarani village, July 2008 to December 2009

\begin{tabular}{|c|c|c|c|c|c|}
\hline \multirow[b]{2}{*}{ Traditional food - species (family) } & \multirow[b]{2}{*}{ Abandonment } & \multicolumn{3}{|c|}{ Maintenance } & \multirow{2}{*}{$\begin{array}{l}\text { Substitution for } \\
\text { industrialized products }\end{array}$} \\
\hline & & Original $^{*}$ & Mixedt & Tradeł & \\
\hline White peanut - Arachis hypogaea L. ssp. (Fabaceae) & $\mathrm{X}$ & & & & \\
\hline Kaguijy§ - Zea mays L. ssp. (Poaceae) & $\mathrm{X}$ & & & & \\
\hline Green banana - Musa spp. van Grand Nain (Musaceae) & & $\mathrm{X}$ & & & \\
\hline Peach palm heart - Bactris gasipaes Kunth (Palmae) & & $\mathrm{X}$ & & & \\
\hline Jussara palm heart - Euterpe edulis Martius (Palmae) & & $\mathrm{X}$ & & & \\
\hline Cassava - Manihot esculenta Crantz (Euphorbiaceae) & & & $\mathrm{X}$ & & \\
\hline Corn - Zea mays L. ssp. (Poaceae) & & & $\mathrm{X}$ & & \\
\hline Peanut - Arachis hypogaea L. ssp. (Fabaceae) & & & $\mathrm{X}$ & & \\
\hline Yerba mate - Ilex paraguariensis St. Hil. (Aquifoliaceae) & & & $\mathrm{X}$ & & \\
\hline Cowpea - Vigna unguiculata (L.) Walp. (Fabaceae) & & & & $\mathrm{X}$ & \\
\hline Sweet potato - Ipomoea batatas Lam. (Convolvulaceae) & & & & $\mathrm{X}$ & \\
\hline Orange - Citrus sinensis L. ssp. Osbeck (Rutaceae) & & & & $\mathrm{X}$ & \\
\hline Peach - Prunus persica (L.) Batsch (Rosaceae) & & & & $\mathrm{X}$ & \\
\hline $\begin{array}{l}\text { Jabuticaba (Brazilian grape tree) - Myrciaria cauliflora (Mart.) } \\
\text { Berg (Myrtaceae) }\end{array}$ & & & & $\mathrm{X}$ & \\
\hline Blackberry - Morus nigra L. (Moraceae) & & & & $\mathrm{X}$ & \\
\hline Bean - Vigna unguiculata (L.) Walp. (Fabaceae) & & & & $\mathrm{X}$ & \\
\hline $\begin{array}{l}\text { Fubá (industrial product from corn) - Zea mays L. ssp. } \\
\text { (Poaceae) }\end{array}$ & & & & & $\mathrm{X}$ \\
\hline Rice - Oryza sativa L. ssp. (Poaceae) & & & & & $\mathrm{X}$ \\
\hline
\end{tabular}

${ }^{*}$ Original $=$ acquisition of plant species according to traditional practices (farming or extractivism).

tMixed $=$ mixed acquisition (farming and trade).

$\ddagger$ Trade $=$ exclusively acquired at markets.

§acred beverage made from fermented corn.

Guarani villages in São Paulo. The village was considered to be one of the few rural villages near the city in which indigenous people have retained knowledge about traditional foods. Using a snowball method ${ }^{(25)}$, fifteen individuals were selected on the basis of preserved knowledge about their past and present eating habits. Each person was visited multiple times to establish a relationship that enabled interviews and observations, and the interviewer was able to record a great deal of knowledge. A Personal Data Sheet recorded each interviewee's name, age and position in the village. A Diet Data Sheet designed specifically for the present study asked the following questions: 'Do you have any illness that you had in the past and have no more?'; 'Do you think this has anything to do with the "new diet"?'; 'Do you eat industrialized food (sugar, coffee, pasta, oil, or salt)?'; 'Do you grow food?'; and 'Do you hunt?'.

Seven men and eight women, ranging in age from 23 to 78 years, were interviewed. The interviewees held different positions in the village, including a chief and vice chief, a counsellor, a leader, a shaman, a teacher and an Indian health-care agent. The education of the interviewees ranged from illiterate to the undergraduate student level. All interviewees had at least some experience growing crops.

\section{Data analysis}

The information obtained from field diaries and interview guides was converted into field reports and was crosschecked for accuracy, according to the cultural anthropology approach $^{(25,28)}$. Field reports included the following: the use of particular food plants and the village preparation processes that were maintained or abandoned over time; whether interviewees established a cause-and-effect relationship with the consumption of food plants/dishes; and the relationship between risk factors, such as disease, and the abandonment of food plants, dishes and preparation processes.

\section{Results and discussion}

\section{Traditional diet}

The authors considered a traditional diet to be any past eating habits in the memory of the Guarani nation. Indians remember these habits from their past and from the stories of their ancestors, or they acquire the knowledge during the frequent events in celebration of traditional Guarani cuisine.

The traditional diet consisted of three daily meals and included food for 'the body' and 'the soul'; the main plant foods reported by the interviewees are described in Table 1. In the morning, the first meal consisted of corn meal, meat and mbojape'i (corn cake). The next meal did not occur at a set time but took place after work and usually included beans with canjica (a dish prepared from corn), meat with cassava flour, cassava and other corn-based dishes. The third meal happened in the late afternoon in the prayer house where the villagers performed rituals while consuming peanuts, honey and a beverage prepared from 
mate (yerba mate, Ilex paraguariensis St. Hil. (Aquifoliaceae), ground and macerated with hot water).

The acquisition of food plants and their preparation processes, but not the number of meals, changed over time.

\section{Dynamics of food acquisition and preparation over time}

\section{Farming}

Farming has become a sporadic activity because of factors related to the urban location of the village, reduction of farming land from urbanization and sandy soils. However, when villagers do farm, they work in accordance with Guarani nation traditions. Farming is always conducted in fields and the farmers observe the specific requirements of each plant, such as when the plant should be sown or harvested, according to the month and moon, the blessing of seeds and the blessing of the shaman to ensure a good harvest.

Farming also formed the base of the diet for other Brazilian Indian nations, such as the Xavante, who grew corn, beans, squash and tubers, but these crops have been replaced by products of mechanized agriculture ${ }^{(29)}$. Among the Wari and Bororo nations, corn, a traditional staple, has also been replaced; the Wari now rely on cassava and the Bororo have switched to rice ${ }^{(30,31)}$. These substitutions have resulted in the loss of traditional seeds and a significant reduction in farming. The agricultural practices of the Parakanã yield inadequate crops of corn and cassava. Thus, market products must complement their food supply, which does not always guarantee a quality diet ${ }^{(17)}$.

The large number of plants domesticated by American Indians may have been their greatest contribution to other populations around the world ${ }^{(32)}$. Their primary crops included tomatoes, potatoes, tobacco, corn, peppers, peanuts, cassava, pineapple, papaya, passion fruit, squash, coca, sweet potatoes, beans, peach palm, açaí and annatto. The INSNPI ${ }^{(20)}$ showed that the most frequently grown crops in Brazilian Indian gardens and fields in 2008 and 2009 were cassava $(97 \cdot 3 \%$ of villages), corn $(89 \cdot 1 \%)$, beans $(63.6 \%)$ and rice (30.9\%). In south and south-eastern Brazil, where the village of the present study is located, corn was grown in all of the villages that were visited, as observed in the studied village.

In a study on Atlantic forest resources, which is the biome that covers the Guarani villages, some of the plants that were used in traditional Indian diets, such as cassava and banana, were also observed in the diets of coastal caiçara fishermen ${ }^{(33)}$. These plants can be grown next to houses, and such ease of growing explains the use of these crops among different populations. However, they were cultivated only sporadically and in small quantities in the studied village.

The traditional varieties of corn are rarely found in markets and seed stores. They are obtained in scarce quantities mainly through donations and exchanges with other villages. As such, the Indians began to buy and cultivate the currently used varieties of corn, which have been commercially available since the 1960s. Beyond the cultivation, natives acquire corn (fresh cobs) and its industrialized derivatives, such as fubá, through trade (Table 1). Dishes such as canjica, for example, are prepared from these corn sources.

\section{Hunting}

Although the Guarani have been described as hunters ${ }^{(34)}$, hunting gradually diminished in the studied population after urbanization and agricultural practices around the village reduced the number of animals. The same pattern was observed among the Xavante ${ }^{(29)}$, but they have been developing management strategies to preserve resources by respecting the hunting period and the size and age of hunted animals. All Indian populations practised hunting until the early 20th century, but now only $66 \cdot 7 \%$ of Brazilian villages in the south and south-eastern regions still hunt, which is a drastic reduction in the activity according to the INSNPI ${ }^{(20)}$. Conversely, $83 \cdot 3 \%$ of Guarani villages practise fishing, which makes it the most maintained tradition among Brazilian indigenous communities, with prevalence estimates reaching $92 \%{ }^{(20)}$.

\section{Extractivism}

According to the INSNPI ${ }^{(20)}$, the Guarani rely on extractivism in $83.3 \%$ of all south and south-eastern villages. The main foods that are traditionally gathered from the forest include fruits and palm. Because the studied village is currently located within an Environmental Protection Area, extractivism is restricted to village lands, where villagers collect fruits such as jaboticaba (Brazilian grape tree), oranges, bananas and palm (Table 1).

Because of farming, hunting and extraction limitations in the studied village, the Guarani had to find a method of acquiring resources to complement their traditional diet. Their solution, which was to trade food with outside groups, resulted in changes to the indigenous diet that include the abandonment and maintenance of certain foods, the substitution of industrialized products and the incorporation of new items. Food items such as white peanuts were abandoned over time (Table 1). Other foods such as itio (which is the larvae removed from decomposing palm hearts) and kaguity (a sacred beverage from the fermentation of green corn that is consumed by the elderly) are no longer consumed.

The consumption of different varieties of the same plant species has been reported over time. However, in the case of the maintenance of traditional foods, food acquisition occurs in three ways: (i) original, where acquisition (farming or extractivism, depending on food item) has remained the same; (ii) mixed, where farming had to be complemented by trade; and (iii) trade, where food items are now acquired exclusively at local markets because they are no longer available in the village (Table 1). 
The following food items were maintained in the original way: jussara and peach palm hearts are extracted, and bananas are farmed. The acquisition of yerba mate, cassava, peanuts and traditional corn is mixed because cultivation was not sufficient for frequent consumption. Among food items that are consumed 'for the body', corn is the most important staple food in the traditional diet, present in seven of the twelve recipes used daily. Conversely, the consumption of fruits, beans and sweet potatoes is only possible because of their market availability, as they are no longer found in the village (Table 1).

The substitution of industrialized products was observed for rice and fubá (industrial product from corn), which were previously grown and produced in the village, respectively (Table 1). Their consumption is only made possible by their market availability, but the products have undergone industrial processes. Additionally, native honey was replaced by industrialized sugar.

Owing to the close proximity to markets, new foods have been incorporated into the daily habits of the village. New foods include salt, oil, coffee, milk, pasta, spices, bread, wheat, soft drinks, baking powder, cookies and candy. The incorporation of these foods has resulted in non-indigenous dishes and the adaptation of traditional recipes. The $x i p a$, for example, is part of the daily village life; this fried dish was adapted from kavure (a wheat-based baked recipe) and requires baking powder and salt.

The centuries-old habit of Guarani farming has been reported by several authors ${ }^{(35)}$. Farming of staple foods, such as corn, as well as hunting and extractivism practices, were reported by interviewees, in agreement with reports about the eating habits and ethnic identities of a Guarani village in the state of Rio Grande do Sul ${ }^{(36)}$. Diet changes and the market acquisition of food items were also mentioned by the author and support the information provided by the INSNPI ${ }^{(20)}$, which found that $99 \cdot 1 \%$ of households purchased food in the south and south-eastern regions. Among the items purchased, fat, salt and sugar were used in $99.6 \%$ of households.

Food changes have occurred after the Industrial Revolution. The need for higher productivity and the promotion of trade among countries and continents have favoured the replacement of certain difficult-to-obtain foods and have led to the incorporation of new foods into the diet ${ }^{(37)}$. Thus, the pattern observed in the present study is similar to the global pattern, which persists even though the village is located in a rural area where the continued cultivation of food is possible. Several studies and the INSNPI have also detected this global pattern in the Brazilian indigenous population ${ }^{(20,29-31,34,36)}$. There has been a clear tendency for natural diets to shift to industrialized product-based diets.

\section{Interviewee perceptions about the relationships among food, bealth and disease}

To understand interviewees' perceptions about the relationships among food, disease and health, these concepts were examined within the ethnic group. According to the interviewees, food transcends the notion of simply feeding 'the body' (i.e. corn). Food is also consumed 'for the soul' (i.e. tobacco, or Nicotiana spp. L. (Solanaceae)). Some foods, such as yerba mate, feed both body and soul. This indigenous population believes that the body may be harmed when not fed properly, mainly by growing weak. However, if the 'soul is not fed' or purified, it becomes impossible to communicate with Nhanderu (the Guarani God), which causes a series of difficulties and cultural impediments for the entire group.

Interviewees recognize that health goes beyond the reverence for Nhanderu, demarcation of their land and cultural practice; they know that they also need to eat healthily, which involves feeding the body and soul with traditional foods, including corn, sweet potatoes, boiled green bananas, game meat, tobacco and yerba mate. Yerba mate, in particular, is used for energy, protection and the prolonging of life expectancy.

For the Guarani nation, diseases are divided into 'earth' and 'spirit' categories. Diseases of the spirit are those 'that only the shaman can heal', whereas earth diseases are 'white man's diseases'. In the past, only diseases of the spirit existed, such as 'stone in the body'. This disease is experienced when a person enters a river, lake or cemetery without the permission and blessing of the shaman. If the person is going through a spiritual moment during which he/she should not contact the water or the cemetery spirits, the person's muscles become stiff and painful. Another disease of the spirit is 'headache'. According to interviewees, the occurrence of these illnesses has increased considerably because villagers have not observed traditions or paid obedience to the shaman. This abandonment of traditions is attributed to modernization and the arrival of technology. New habits include watching television, listening to the radio and failing to observe traditions such as visiting the prayer house.

Earth diseases, on the contrary, include fever, cough, toothache, influenza, tuberculosis, pneumonia and infectious disease. These illnesses have also changed and have increased over time. The interviewees attribute some of these changes to a diet full of chemical preservatives, pollution and fat. The new diet comes from the intimate contact with non-indigenous populations. The interviewees believe that the new diet is fattening and induces disease. These views support information provided by nurses who tend to the Tenondé Porã village; approximately $35 \%$ of children aged between 1 and 5 years are malnourished.

Some studies corroborate the information obtained in the present study. Malnutrition was observed at all ages, and obesity was observed among adults in all studies that analysed the nutritional status of various Brazilian indigenous groups ${ }^{(16,18,19,21,30)}$ and several traditional groups in Canada $^{(6,7)}$, the USA ${ }^{(8-12)}$ and Mexico ${ }^{(13,14)}$. Some studies demonstrate that the rapid dietary transition in traditional 
and indigenous communities has contributed to a high risk of chronic disease ${ }^{(38)}$, as suggested by the Indian respondents.

Studies on the morbidity and mortality of Guarani people in south and south-eastern Brazil ${ }^{(39,40)}$ have reported an annual rate of hospitalization ( 8.8 per 100 people) that exceeds the average for any Brazilian region. Respiratory illnesses were responsible for $64 \cdot 4 \%$ of all hospitalizations in 2007 and 2008. Secondary causes of hospitalizations included Fe-deficiency anaemia $(13.8 \%)$ in children under 1 year of age, malnutrition and dehydration (23.6\%) and diarrhoea and septicaemia (16.7\%) in children aged 1 to 4 years $^{(37)}$. The main causes of mortality are malnutritionaggravated disease, such as acute respiratory illnesses and diarrhoea ${ }^{(39)}$. In Parakanã villages in the Amazon, malnutrition was positively associated with the length of contact with non-indigenous cultures near the village ${ }^{(17)}$. The INSNPI ${ }^{(20)}$ presented disturbing morbidity rates among 14- to 19-year-old women in the south and south-eastern regions, which are listed as follows: $28 \cdot 8 \%$ had abnormal blood pressure; $25.4 \%$ had an abnormal blood sugar level; $30.6 \%$ of non-pregnant women and $28.0 \%$ of pregnant women were anaemic (2.5\% had severe anaemia); $2 \cdot 4 \%$ were underweight; $32 \cdot 2 \%$ were overweight; and $22 \cdot 4 \%$ were obese. Among children under 5 years of age in the same region, $8 \cdot 0 \%$ were born at a low birth weight, $48 \cdot 5 \%$ had anaemia at the time of the visit and were below average weight and height.

The epidemiological data presented above agree with the perceptions of the respondents. According to them, close contact with non-indigenous peoples was responsible for the abandonment of Guarani traditions and increased the frequency and types of diseases. Many diseases are directly associated with eating habits, including respiratory diseases, food-related diseases (anaemia, diarrhoea and malnutrition) and chronic diseases (hypertension, diabetes and obesity). For the Guarani health depends on respecting traditional cultural practices.

\section{Conclusions}

Given the data found in the present study, the main factors that have likely resulted in Guarani diet changes include the village's proximity to the city, increased contact with non-indigenous populations and the existence of financial resources. Both the rural location of the Guarani village and the Environmental Protection Area surrounding the small demarcated area exclude the possibility of farming, extraction and hunting. This situation has led the people to obtain most of their food at markets and has resulted in the abandonment and substitution of some food items.

The main Guarani crops are corn, yerba mate and tobacco, which provide nourishment for body and soul. They are still used regularly, considered sacred and linked to no health problems.
According to the reports from Indian interviewees, several factors have increased the frequency of disease. These factors are always associated with the abandonment of Guarani traditions such as changes in diet and include the introduction of new food items and preparation processes, lack of obedience to Nhanderu and lack of adequate space for farming and hunting. These changes have contributed to a sedentary lifestyle, which has a proven correlation with disease prevalence.

\section{Acknowledgements}

Source of funding: The authors thank CAPES (Coordenação de Aperfeiçoamento de Pessoal de Nível Superior) for financial support and the Department of Psychobiology and AFIP (Associação Fundo de Incentivo à Psicofarmacologia) for infrastructure support. Conflicts of interest: The authors declare no conflicts of interest. Authors' contributions: N.S. and E.R. designed and conducted the research and wrote the manuscript. Acknowledgements: The authors thank Professor Elisaldo Carlini for guidance and conversations, Professor João Henrique Ghilardi Lago for assistance and Maria Perpétua Socorro Leite Bernardo for support. Finally, they thank the Tenondé Porã village for the opportunity to live together.

\section{References}

1. Canesqui AM (1988) Antropologia e alimentação. Rev Saude Publica 22, 207-216.

2. Murrieta RSS (2001) Dialética do sabor: alimentação, ecologia e vida cotidiana em comunidades ribeirinhas da Ilha de Ituqui, Baixo Amazonas, Pará. Rev Antropologia 44, 39-88.

3. Cascudo LC (2004) História da Alimentação no Brasil. São Paulo: Global.

4. Gomes MP (2006) Ser presidente da FUNAI já é uma glória: entrevista à equipe da edição. In Povos Indigenas do Brasil: 2001/2005, pp. 109-119 [B Ricardo and F Ricardo, editors]. São Paulo: Instituto Socioambiental.

5. Wallace S (2007) Amazônia Ilegal. National Geographic 7, 20-51.

6. Ritenbaugh C, Szathmary EJE, Goodby CS et al. (1996) Dietary acculturation among the Dogrib Indians of the Canadian Northwest Territories. Ecol Food Nutr 35, 81-94.

7. Willows ND (2005) Determinants of healthy eating in aboriginal peoples in Canada - the current state of knowledge and research gaps. Can J Public Health 96, 32-36.

8. Harnack L, Story M \& Rock BH (1999) Diet and physical activity patterns of Lakota Indian adults. J Am Diet Assoc 99, 829-835.

9. Redwood DG, Ferucci ED, Schumacher MC et al. (2008) Traditional foods and physical activity patterns and associations with cultural factors in a diverse Alaska native population. Int J Circumpolar Health 67, 335-348.

10. Yang RC \& Mills PK (2008) Dietary and lifestyle practices of Hmong in California. J Health Care Poor Underserved 19, 1258-1269.

11. Jollie-Trottier T, Holm JE \& Mcdonald JD (2009) Correlates of overweight and obesity in American Indian children. J Pediatr Psychol 34, 245-253. 
12. O'Connell M, Buchwald DS \& Duncan GE (2011) Food access and cost in American Indian Communities in Washington State. J Am Diet Assoc 111, 1375-1379.

13. Rodriguez-Moran M, Guerrero-Romero F \& RasconPacheco RA (2009) Dietary factors related to the increase of cardiovascular risk factors in traditional Tepehuanos communities from Mexico. A 10 year follow-up study. Nutr Metab Cardiovasc Dis 19, 409-416.

14. Monarrez-Espino J, Greiner T \& Hoyos RC (2004) Perception of food and body shape as dimensions of western acculturation potentially linked to overweight in Tarahumara women of Mexico. Ecol Food Nutr 43, 193-212.

15. Saunders JB (2007) 'I don't eat meat': discourse on food among transnational Hindus. Contrib Indian Sociol 41, 203-223.

16. Gugelmin AS \& Santos RV (2001) Ecologia humana e antropometria nutricional de adultos Xavante, Mato Grosso, Brasil. Cad Saude Publica 17, 313-322.

17. Martins SJ \& Menezes RC (1994) Evolução do estado nutricional de menores de 5 anos em aldeias indígenas da Tribo Parakanã, na Amazônia Oriental Brasileira (1989-1991). Rev Saude Publica 28, 1-8.

18. Morais MB, Fagundes-Neto U, Mattos AP et al. (2003) Estado nutricional de crianças índias do Alto Xingu em 1980 e 1992 e evolução pondero-estatural entre o primeiro e o quarto anos de vida. Cad Saude Publica 19, 543-550.

19. Pícoli RP, Carandina L \& Ribas DLB (2006) Saúde maternoinfantil e nutrição de crianças Kaiowá e Guaraní, Área Indígena de Caarapó, Mato Grosso do Sul, Brasil. Cad Saude Publica 22, 223-227.

20. Coimbra CEA Jr (general coordinator) (2009) Inquérito Nacional de Saúde e Nutrição dos Povos Indígenas: Relatório Final. Rio de Janeiro: without publisher.

21. Port Lourenco AE, Santos RV, Orellans JDY et al. (2008) Nutrition transition in Amazonia: obesity and socioeconomic change in the Surui Indians from Brazil. Am J Hum Biol 20, 564-571.

22. Instituto Socioambiental (2006) Localização das aldeias Guarani no Brasil. In Aldeias Guarani Mbya na Cidade de São Paulo, p. 9 [R Gauditano, editor]. São Paulo: Studio RG.

23. Instituto Socioambiental (2011) Povos Indígenas do Brasil. http://www.socioambiental.org.br (accessed October 2011).

24. Conservation International (2011) Biodiversity hotspots. http://www.biodiversityhotspots.org/xp/Hotspots/andes/ (accessed March 2011).
25. Bernard HR (1988) Research Methods in Cultural Anthropology. Newbury Park, CA: Sage.

26. Malinowski B (1990) O objeto, método e alcance dessa pesquisa. In Desenvolvendo Máscaras Sociais, pp. 39-61 [AZ Guimarães, editor]. Rio de Janeiro: Francisco Alves.

27. Martin GJ (1995) Ethnobotany: A Methods Manual. London: Chapman \& Hall.

28. Alexiades MN (1996) Selected Guidelines for Ethnobotanical Research: A Field Manual. New York: The New York Botanical Garden.

29. Silva RJN \& Garavello MEPE (2009) Alterações nas estratégias de subsistência: o caso dos Índios brasileiros Xavantes. Rev Seg Aliment Nutr 16, 32-48.

30. Pinto JG \& Garavello MEPE (2002) Transformação (agri)cultural ou etnossustentabilidade: relato de uma aldeia Bororo. Agroecol Desenvolv Rural Sustent 3, 54-60.

31. Leite MS (2007) Transformação e Persistência: Antropologia da Alimentação e Nutrição em uma Sociedade Indígena Amazônica. Rio de Janeiro: Fiocruz.

32. Neves EG (1995) Os índios antes de Cabral: arqueologia e história indígena no Brasil. In $A$ Temática Indigena na Escola: Novos Subsidios para Professores de $1^{\circ}$ e $2^{\circ}$ Graus, pp. 171-196 [AL Silva and LDB Grupioni, editors]. Brasilia: MEC/MARI/UNESCO.

33. Hanazaki N, Leitão-Filho HF \& Begossi A (1996) Uso de recursos na Mata Atlântica: o caso da Ponta do Almada (Ubatuba, Brasil). Interciencia 21, 268-276.

34. Brandão CR (1990) Os Guarani - índios do Sul - religião, resistência e adaptação. Estud Av 4, 53-90.

35. Ladeira MI \& Matta P (2004) Terras Guarani no Litoral: As Matas que Foram Reveladas aos nossos Antigos Avós. São Paulo: Centro de Trabalho Indigenista.

36. Tempass MC (2005) Orerémbiú: a relação das práticas alimentares e seus significados com a identidade étnica e a cosmologia Mbyá-Guarani. Master's Thesis, Universidade Federal do Rio Grande do Sul.

37. Bleil SI (1998) Mudança de hábitos a partir da industrialização agroalimentar. Master's Thesis, Universidade Federal Rural do Rio de Janeiro.

38. Whiting SJ \& Mackenzie ML (1998) Assessing the changing diet of indigenous people. Nutr Rev 56, 248-250.

39. Cardoso AM, Coimbra CEA Jr \& Tavares FG (2010) Hospital morbidity among Guarani Indians in southeastern and southern Brazil. Rev Bras Epidemiol 13, Suppl. 1, 21-34.

40. Cardoso AM, Coimbra CEA Jr, Barreto CTG et al. (2011) Mortality among Guarani Indians in southeastern and southern Brazil. Cad Saude Publica 27, 222-236. 